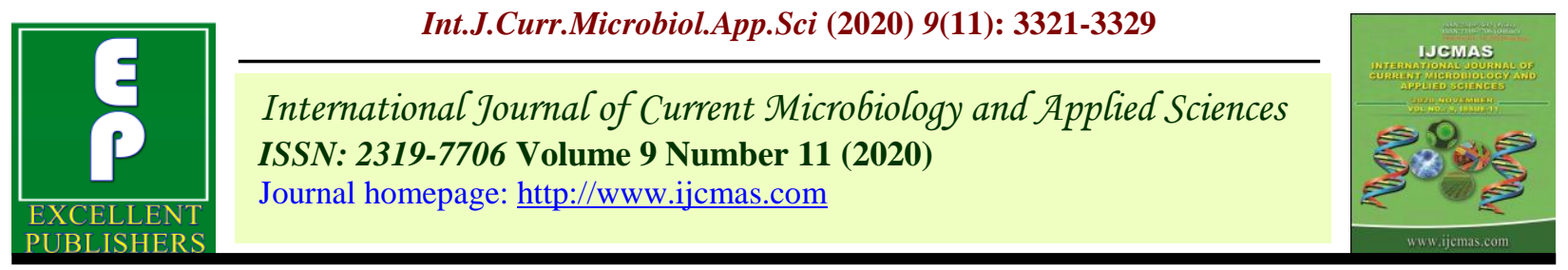

Review Article

https://doi.org/10.20546/ijcmas.2020.911.397

\title{
Ex-vitro Establishment of Tissue Cultured plants in Fruit Crops-A Review
}

\author{
Rohit Mahendra*, Nidhi Chauhan, Jyoti Bharti Sharma, \\ Kanchan Rana and Manish Bakshi
}

School of Agriculture, Lovely Professional University, Punjab, India

*Corresponding author

\section{A B S T R A C T}

Keywords

Heterotrophic, Acclimatization, Growth, Ex-vitro, Greenhouse

\section{Article Info}

Accepted:

22 October 2020

Available Online:

10 November 2020
In vitro multiplied plants possess the poor physiology due to heterotrophic nature and cannot survive in the harsh environmental conditions such as high irradiance, low relative humidity, high \& low temperatures and the septic conditions when transferred from lab to land. Therefore, most of the in vitro grown species requires the acclimatization process under ex-vitro conditions to ensure the maximum survival and vigorous growth. The acclimatization is a gradual process and often carried out inside the greenhouse. This review emphasizes on the physiological, anatomical and morphological factors that are responsible for delicacy of in vitro cultured fruit crops and the ways to overcome these problems.

\section{Introduction}

Micropropagation is a very popular technique of producing a large no. of plants under aseptic conditions and has been applied for commercial plant production over 30 years. Initially it was limited to certain ornamental crops but nowadays it encompasses fruit crops as well as other horticultural crops. The problems lie with tissue cultured plants are fragile nature, abnormal morphology, physiology and anatomy and inability to withstand the unfavourable environmental conditions due to the heterotrophic mode of nutrition (Hazarika, 2006). Micro-propagated plants lack the cuticle layer, stomata closure, chlorophyll content and have poorly developed roots which are then accompanied by the transpirational losses, low humidity and pest \& diseases when transferred to $e x$ vitro conditions (Bhatia, 2015; Chandra et al., 2010). Hence, hardening of the cultured plants under ex vitro conditions must be carried out to get the desired outcome. Acclimatization of regenerated plantlets is accomplished primarily in mist chamber or greenhouse and then in secondary hardening chambers like shade net houses under partial shade. Generally, the regenerated plantlets are separated completely from the existing MS medium and thorough washing of roots is done in order to remove the medium. Plantlets 
are then transferred to the pots carrying the hardening substrate cocopeat, sand, soil and FYM in combination or alone. The relative humidity is maintained near about $95 \%$ and plants are kept covered with plastic sheets or inverted glass jars to avoid transpirational water losses. In order to make the plants acclimatized, moisture content and the amount of nutrients is reduced gradually and the plants are transited to shade net house for further hardening (Bhalsing et al., 2001).

By this process, wax layer is formed, and leaf thickness increases and the density of stomata decreases resulting in stabilization of water status (Pospíšilová et al., 1999). Tissue cultured plants generally undergo the transplantation shock, as a result, high mortality is experienced (Dhawan and Bhojwani, 1986). Therefore, the plantlets can be partially hardened off in vitro by decreasing the $\mathrm{RH}$ and increasing the light intensity before removing them from the culture medium (Maene, 1985). The transplantation shock can also be alleviated by the addition of ABA immediately to the substrate (Pospíśilová et al., 1998). It is evident from the studies that, mycorrhizal fungi have great role in terms of enhancement in gas exchange and nutrient uptake during acclimatization of fruit crops (Luna et al., 2000; Schubert and Lubraco, 2000; Quatrini et al., 2003). Increased concentration of sucrose supplemented in culture medium increases the carbohydrate content and decreases size of stomata during ex vitro establishment (Jo et al., 2009).

Physiological, morphological and anatomical factors affecting the ex-vitro survival of micro-propagated plants

\section{Cuticle}

Plant cuticle is a protective covering of the leaf epidermis, young shoots and other aerial parts of plant. This layer is made up of insoluble cuticular membrane and filmed with soluble epicuticle waxes. Cuticle serves as the barrier for the water permeability and prevents the water loss from epidermal surface by the evaporation. Studies indicate that the crystalline structure of epicuticle waxes on surface of in vitro raised plants varies significantly from the ex vitro grown plants (Preece and Sutter, 1991). However, in vitro grown plantlets can resemble greenhouse raised plants in terms of anatomy of leaves under the modified environmental conditions of lower $\mathrm{RH}(75 \%)$ and higher light levels in vitro (Capellades et al., 1990).

\section{Chlorophyll content}

Chlorophyll is a green pigment of plant leaves which is very essential for the photosynthesis. The heterotrophic conditions and prolonged dark period alter the biosynthesis of chlorophyll in the plants resulting in poor photosynthetic capacity (Donnelly and Vidaver, 1984). Similarly, due to the lack of light quality, mineral nutrition (especially $\mathrm{N}$, $\mathrm{Mg} \& \mathrm{Fe}$ ) and chemical metabolites produced in plants, chlorophyll activity and formation is also influenced (Ahmad et al., 2018). As a result, the plantlets appear pale yellow and do not participate actively in photosynthesis when transplanted to ex vitro conditions. Dobranszki and Drienyovszki, (2014), reported the increased chlorophyll content during in vitro culture of apple with BA. However, the BAP induced the long term defects in the Aechmea blanchetiana during in vitro propagation (Martins et al., 2018).

\section{Stomata}

Stomata of in vitro grown plants are circular in shape and are invariably opened which may be caused by higher relative humidity inside the incubation room (Wetzstein and Sommer, 1983; Wardle and Short, 1983). Due to the 
presence of these deformed stomata, excessive loss of water from the plants occurs under the field conditions (Ziv et al., 1987). Some growth regulators such as Abscisic acid act as strong inihibitor of this stomatal collapse but this event can be reversed with the exogenous application of IAA and cytokinins (Wright and Hiron, 1969; Pemadasa, 1982; Blackman and Davies, 1983).

\section{Root growth}

Micro-propagated plants have relatively poor root growth than those plants cultivated in vivo. The reason may be the presence of shallow culture medium which inhibits the root elongation. The roots of in vitro cultured plants generally have the underdeveloped vascular system than the ex vitro raised plants (McClelland et al., 1990). However, maximum root initiation (90-100\%) can be obtained in apple with the medium containing coarse sand, perlite, rotated liquid medium and agar but root growth is reduced in agar (Hutchinson, 1984). IBA is a promising growth regulator in terms of root induction and is used at large scale. Application of IBA @ $10^{-6} \mathrm{M}$ significantly increased the number and length of roots in jackfruit under $12 \mathrm{~h}$ light period (Rahman and Blake, 1988). Likewise, Dinesh et al., (2019), obtained the higher ex vitro rooting of pomegranate than in vitro conditions with $1476 \mu \mathrm{M}$ IBA treatment and maximum survival during acclimatization.

\section{Ex vitro establishment of micro-propagated fruit crops}

\section{Banana}

In-vitro cultivated plants are raised in a protected environment and shifting these cultured plantlets in to the main field in open conditions requires some preconditioning of the plants-generally referred to as hardening.
In-vitro culture of banana plants is in vogue as banana is marred with a host of viral diseases. So orchardists now-a-days are relying more on micro-propagated banana plantlets which are virus free. To cater to the increasing demand for tissue cultured banana plants, a lot of bio-tech labs are now producing tissue cultured plants following standard procedures so as to reduce the mortality rate of the saplings when these are shifted to the open field conditions. Bari banana 1 cultivar showed maximum survival up to $95-100 \%$ after $15-20$ days of in vitro culture on IBA $(0.4-0.6 \mathrm{mg} / \mathrm{L})$ with 7 days hardening at room temperature (Molla et al., 2004). Similarly, it was observed that micropropagated saplings of in vitro propagated Red banana may be hardened by using red soil + sand + coco peat $(1: 1: 1 \mathrm{v} / \mathrm{v})$ combination (Uzaribara et al., 2015) which resulted in maximum survival up to $95 \%$. Grand Naine, a prominent cultivar of banana showed highest survival rate $(100 \%)$ of micro-propagated plants during acclimatization with the potting mixture soil: sand: FYM (2:1:1) and covering the plants with glass beakers (Ahmed et al., 2014). Similarly, other potting mixtures were tried for hardening of the banana plants and it was found that the best combination of potting medium for hardening of in vitro cultured banana cv. Amritpani was soil: FYM: sand in the proportions of $1: 1: 1$. This combination also increased plant height and root growth (Maharana et al., 2017).

Culture medium augmented with antibiotic rifampicin for difficult to-establish banana cultivar Elakki Bale during in vitro cultivation helps in maintaining the aseptic culture and resulted in higher survival (96.3\%) of plantlets during ex vitro establishment (Bohra et al., 2014). 'Williams' banana treated with topolines synthesized the higher amount of phenolics in greenhouse-acclimatized plants when compared with cytokinins, which led to 
increased survival rates in the banana plants (Aremu et al., 2012).

\section{Apple}

Desiccation of the plantlets due to the lack of proper closure of stomata is commonly found when the plants are separated from the hetrotrophic conditions (Brainerd and Fuchigami, 1982). The stomata of in vitro raised apple plantlets lose their regulatory ability which is the possible reason of excessive water loss from plant through transpiration (Blanke and Belcher, 1989). Therefore, the exposure of in vitro grown apple shoots to high relative humidity (90\%) and high boundary layer conductance may result into the development of functional stomata (Shackel et al., 1990). In micropropagated apple, rooting of plantlets is a difficult task and leads to the death of plant when not subjected to acclimatization. Acclimatization of in vitro derived apple micro-cuttings resulted in more number and length of the roots in the phototron units than in the greenhouse under fog system (Skirvin and Sriskandarajah, 1993). In vitro propagated apple rootstock M9 grown in coco peat exhibited the maximum survival than in the soil and achieved 95\% hardening during October-March (Modgil et al., 2009).

IBA treated apple shoots followed by acclimatization in plastic covered pots gave $70 \%$ to $100 \%$ vigorously growing shoots in the greenhouse (Bolar et al., 1998). Similarly, emergence of new leaves and shoots in the apple plants was observed on the fourth day of acclimatization at $95 \%$ relative humidity inside a transparent plastic box (Juan et. al., 1995). Pre-acclimation of cultured plants at $90 \%$ RH one week before the actual hardening results in less transpirational losses and higher survival rate of the plants $(95 \%)$ after transplanting (Ko et al., 2017).
Inoculation of the micropropagated apple plants with mycorrhiza during the ex vitro hardening also enhances the growth and nutrient uptake. Tissue cultured plants of the apple rootstock MM 106 inoculated with Glomus mosseae (Arbusicular mycorrhiza) resulted in heavy colonization of fungi with the roots of plants and increased $\mathrm{P}$ uptake under different substrates (Schubert and Lubraco, 2000).

\section{Grapevine}

In grapevine, hardening of plants using potting mixtures has been demonstrated for survival (Dev et al., 2019). Most suitable potting mixture for the hardening of micropropagated grape cultivars constituting coco peat + vermiculite + perlite $(2: 1: 1)$ resulted in highest survival $(85.97 \%)$ of the plants within shorter period of 24 days. Similar conclusion was made by Jamwal et al., (2013), with substrates sand: soil: FYM: vermiculite (1:1:1:1), resulted in $73.33 \%$ plants survival. Higher rooting of non-rooted in vitro raised grape cultivar 'Norton' with 1000 ppm IBA under ex vitro acclimatization has been demonstrated by Bigger, (2010). Application of bio-agents in the acclimatization process of young in-vitro grown plantlets has been demonstrated (Krishna et al., 2005). Inoculation of in vitro cultured grapevines with arbuscular mycorrhizal fungi (AMF) during hardening showed improved physiological conditions and nutrient status as well as higher photosynthetic rate. The best substrate for hardening of grape rootstock Paulsen 1103 and for growth of mycorrhiza was soil, compost and sand (Zemke et al., 2003). Whereas, Barreto and Nookaraju, (2007) reported the best rooting medium for two grape cultivars 2A-Clone and Red Globe, composed of Coco-peat in combination with sand and soil for quick establishment and hardening of plantlets. 
Higher ex vitro survival rate $(>90 \%)$, number of shoots per plant, vigorous growth and viability of table grapevine cv. Napoleon is obtained with in vitro application of BA (2 $\mathrm{mg} / \mathrm{L}$ ) (Ibañez et al., 2005). In grapes, new leaves which are formed during ex vitro acclimatization generally have higher photosynthetic rate than those formed in vitro (Carvalho et al., 2001).

\section{Strawberry}

Root formation of three strawberry cultivars namely Senga Sengana, Kent and Kama between in vitro and ex vitro conditions was compared and reported that the largest root system is found under ex vitro conditions (Borkowska, 2001). However, in vitro grown strawberry plants on sucrose medium may have better photosynthetic rate under both in vitro as well as ex vitro conditions (Yue et al., 1993). Garfias et al., (2006), obtained 90\% survival of in vitro grown strawberry in the greenhouse with intermittent misting $(80 \%$ $\mathrm{RH})$.

\section{Citrus}

Application of anti-transpirants can propel the hardening process and open field establishment of the in vitro raised plants in citrus (Hazarika and Parthasarathy, 2002). The reduced water loss and maximum ex vitro survival of citrus with in vitro application of antitranspirant 8-hydroxyquinoline (2 mg/L). Hazarika et al., (2001) recorded increased plant height, reduced size of stomata and maximum survival rate $(94.6 \%$ to $97.2 \%)$ of four citrus species with the in vitro application of paclobutrazol (1 mg/L). 100\% survival of in vitro raised citrus limon plantlets during ex vitro weaning process is reported with mycorrhizal species Glomus mosseae along with increased plant height, root \& shoot weight, phosphorous content, ratio of shoot/root and leaf area (Quatrini et al., 2015). Similar results were obtained by the $\mathrm{Wu}$ et al., (2011) in micropropagated citrus with Glomus mosseae, which led to the better ex vitro adaptation of plantlets, enhanced nutrient uptake and maximum photosynthetic rate.

Application of two derivatives of auxin (1.0 $\mathrm{mg} / \mathrm{L} \mathrm{NAA}+1.5 \mathrm{mg} / \mathrm{L}$ IBA) together in the culture enhanced in vitro rooting, survival rate and shoot growth during acclimatization stage in citrus cultivars Orange Pear and Rangpur Lime (Soares and Miranda, 2016).

In conclusion the ex-vitro establishment of tissue cultured plants is a mandatory process without which field survival of the plants is almost impossible. Acclimatization modifies several physio-morphological parameters in plants such as reduction in the stomatal numbers, increased leaf thickness, increased chloroplast numbers and vigorous root growth. It is, however, labour and time intensive process but ensures the maximum growth and endurance of in vitro raised fruit crops.

\section{References}

Ahmad, H. R., and Ishaq G (2018). Effects of Rare Earth Oxide Nanoparticles on Plants. Science Direct, Nanomaterials in Plants, Algae and Microorganisms, Concepts and Controversies 1: 239-275.

Ahmed, S., Sharma, A., Bhushan, B., Wali, V. K., Bakshi, P., and Singh, A. K. (2014). Studies on Hardening and Acclimatization of Micropropagated Plantlets of Banana cv. Grand Naine. The Bioscan 9(3): 965-967.

Aremu, A. O., Bairu, M. W., Szu“čova, L., Dolez, K., Finnie, J.F. and Johannes, S. V. (2012). Assessment of the Role of Meta-topolins on In vitro Produced Phenolics and Acclimatization Competence of Micropropagated 
'Williams' Banana. Acta Physiol Plant 34: 2265-2273.

Barreto, M. S., and Nookaraju, A. (2007). Effect of Auxin Types on In vitro and ex vitro Rooting and Acclimatization of Grapevine as Influenced by Substrates. Indian Journal of Horticulture 64(1): 511.

Bhalsing, S. R., Teli, N. P., Pawar, P. K., Saindane, P. V., Baviskar, M. P., and Maheshwari, V. L. (2001). Tissue Culture Grown Banana: A Cost Effective Strategy for Hardening. Physiol. Mol. Biol. Plants 7(2): 185189.

Bhatia, S. (2015). Plant Tissue Culture. Modern Applications of Plant Biotechnology in Pharmaceutical Sciences 31-107.

Bigger, B. B. (2010). Micropropagation and Acclimatization of 'Norton' Grapevine (Vitis aestivalis). Ph.D. Thesis, University of Nebraska - Lincoln, USA $35 \mathrm{pp}$.

Blackman, P. G., and Davies, W. J. (1983). The Effect of Cytokinins and ABA on Stomatal Behaviour of Maize and Commelina. J. Exp. Bot. 34(12): 16191626.

Blanke, M. M., and Belcher, A. R. (1989). Stomata of Apple Leaves Cultured In Vitro. Plant Cell, Tissue and Organ Culture 19: 85-89.

Bohra, P., Waman, A. A., Sathyanarayana, B. N., Umesha, K., Anu, S. R., Swetha, H. G., and Gourish, R. K. (2014). Aseptic Culture Establishment Using Antibiotics with Reference to Their Efficiency and Phytotoxicity in Difficult-to-Establish Native Ney Poovan Banana (Musa, AB). Proc. Natl. Acad. Sci., India, Sect. B Biol. Sci. 84(2): 257- 263.

Bolar, J. P., Norelli, J. L. and Aldwinckle, H. S. (1998). An Efficient Method of Rooting and Acclimatization of Micropropagated Apple Cultivars.
HortScience 33(7): 1251-1252.

Borkowska, B. (2001). Morphological and Physiological Characterstics of Micropropagated Strawberry Plants Rooted In Vitro and Ex Vitro. Scientia Horticulturae 89: 195-206.

Brainerd, K. E., and Fuchigami, L. H. (1982). Stomatal Functioning of In Vitro and Greenhouse Apple Leaves in Darkness, Mannitol, ABA and $\mathrm{CO}_{2}$. Journal of Experimental Botany 33(3): 388-392.

Capellades, M., Fontarnau. R., Carulla, C., and Debergh, P. (1990). Environment Influences Anatomy of Stomata and Epidermal Cells in Tissue-Cultured Rosa multiflora. Journal of American Society for Horticultural Science 115(1): 141-145.

Carvalho, L. C., Osório, L. M., Chaves, M. M., and Amâncio, S. (2001). Chlorophyll Fluorescence as an Indicator of Photosynthetic Functioning of In vitro Grapevine and Chestnut Plantlets Under Ex vitro Acclimatization. Plant Cell, Tissue and Organ Culture 67: 271-280.

Chandra, S., Bandopadhyay, R., Kumar, V., and Chandra, R. (2010). Acclimatization of Tissue Cultured Plantlets: From Laboratory to Land. Biotechnol Lett 32: 1199-1205.

Debergh, P. C., Topoonyanont, N., Huylenbroeck, J. V., Silva, H. M. D., and Oyaert, E. (2000). Preparation of Microplants for Ex Vitro Establishment. Proc. Int. Symp. on Meth. and Mark. Acta Hort. 530: 269-276.

Dev, R., Singh, S. K., Dayal, V., Kumar, K., and Singh, T. (2019). Standardization of In vitro Hardening Strategies for Tissue Cultured Wine Grape (Vitis vinifera $\mathrm{L}$ ) Genotypes. Int. J. Curr. Microbiol. App. Sci. 8(2): 2108-2117.

Dhawan, V., and Bhojwani, S. S. (1986). Micropropagation in Crop Plants. Glimpses in Plant Research 7: 1-75. 
Dinesh, R. M., Patel, A. K., Vibha, J. B., Shekhawat, S., and Shekhawat, N. S. (2019). Cloning of Mature Pomegranate (Punica granatum) cv. Jalore Seedless via In Vitro Shoot Production and Ex Vitro Rooting. Society of Plant Research 32(2): 181-189.

Dobránszki, J., and Drienyovszki, N. M. (2014). Cytokinin-induced Changes in the Chlorophyll Content and Fluorescence of In vitro Apple Leaves. Journal of Plant Physiology 171(16): 1472-1478.

Donnelly, D. J., and Vidaver, W. E. (1984). Pigment Content and Gas Exchange of Red Raspberry In vitro and Ex vitro. J. Amer. Soc. Hort. Sci. 109: 177-181.

Garfias, A. E. J., Sánchez, M. N. V., González, P. A. D., and Razo, A. R. H. (2006). Production and Acclimatization of In Vitro Produced Strawberry Plants. Proc. Xth IS on Plant Bioregulators in Fruit Eds. A.D. Webster and H. Ramirez Acta Hort. 727: 67-72.

Hazarika, B. N. (2006). Morphophysiological Disorders in In Vitro Culture of Plants. Scientia Horticulturae 108(2): 105-120.

Hazarika, B. N. and Parthasarathy, V. A. (2002). Effect of Reduced Humidity and Antitranspirants in Acclimatizing Micropropogated Citrus Plantlets. J. Appl. Hort. 4(1): 30-32.

Hazarika, B. N., Parthasarathy, V. A., and Nagaraju, V. (2001). Influence of In vitro Preconditioning of Citrus Microshoots with Paclobutrazol on Ex vitro Survival. Acta Botanica Croatica 60(1): 25-29.

Hutchinson, J. F. (1984). Factors Affecting Shoot Proliferation and Root Initiation in Organ Cultures of the Apple 'Northern Spy'. Scientia Horticulturae 22(4): 347-358

Ibañez, A., Valero, M., and Morte, A. (2005). Establishment and In vitro Clonal
Propagation of the Spanish autochthonous table grapevine cultivar Napoleon: An Improved System where Proliferating Cultures Alternate with Rooting Ones. Anales de Biología 27: 211-220.

Jamwal, M., Barinder, S., Nirmal, S., and Kumar, R. (2013). In vitro Regeneration of Grape (Vitis vinifera L.) cv. Perlette. W. J. Agric. Sci. 9 (2): 161-66.

Jo, E. A., Tewari, R. K., Hahn, E. J., and Paek, K. Y. (2009). In vitro sucrose concentration affects growth and acclimatization of Alocasia amazonica plantlets. Plant Cell Tiss Organ Cult 96: 307-315.

Ko, S. M., Lee, J. H., and Oh, M. M. (2017). Control of Relative Humidity and Root-zone Water Content for Acclimation of In vitro -Propagated M9 Apple Rootstock Plantlets. Horticulture, Environment, and Biotechnology 59(3): 303-313.

Krishna, H., Singh, S. K., Sharma, R. R., Khawale, R. N., Grover, M., and Patel, V. B. (2005). Biochemical Changes in Micropropagated Grape (Vitis vinifera L.) Plantlets due to Arbuscular Mycorrhizal Fungi (AMF) Inoculation During Ex vitro Acclimatization. Scientia Horticulturae 106: 554-567.

Luna, A. A. E., Davies, F. T. J., and Egilla, J. N. (2000). Mycorrhizal Fungi Enhancement of Growth and Gas Exchange of Micropropagated Guava Plantlets (Psidium guajava L.) during Ex vitro. Mycorrhiza 10: 1-8.

Maene, L. J., and Debergh, P. C. (1987). Optimalisation of the Transfer of Tissue Cultured Shoots In Vivo Conditions. Acta Hort. 212: 335-348.

Maene, L. J. (1985). Optimalisering Van de Overgang Van Weefselteelt Plantjes naar In vivo Omstandingheden. PhD Diss., Gent State Univ., Belgium.

Maharana, K., Munsi, P. S., and Beura, S. 
(2017). Studies on Hardening of In Vitro Plantlets of Banana (Musa acuminata) cv. Amritpani. Multilogic in Science 7(24): 2277-7601.

Martins, J. P. R., Santos, E. R., Rodrigues, L. C. A., Gontijo, A. B. P. L., and Falqueto, A. R. (2018). Effects of 6benzylaminopurine on Photosystem II Functionality and Leaf Anatomy of In vitro Cultivated Aechmea blanchetiana. Biologia Plantarum 62: 793-800.

McClelland, M. T., Smith, M. A. L., and Carothers, Z. B. (1990). The Effect of In vitro and Ex vitro Root Initiation on Subsequent Microcutting Root Quality in Three Woody Plants. Plant Cell, Tissue and Organ Culture 23: 115-123.

Modgil, M., Sharma, T., and Thakur, M. (2009). Commercially Feasible Protocol for Rooting and Acclimatization of Micropropagated Apple Rootstocks. Proc. 1st IS on Biotechnol. of Fruit Species, Acta Hort. 839: 209-214.

Molla, M. M. H., Khanam, M. D., Khatun, M. M., Amin, M. A., and Malek, M. A., (2004). In Vitro Rooting and Ex Vitro Plantlet Establishment of Bari Banana 1 (Musa sp.) as Influenced by Different Concentration of IBA (Indole-3-butyric acid). Asian Journal of Plant Science 3(2): 196-199.

Pemadasa, M. A. (1982). Differential Abaxial and Adaxial Stomatal Responses to Indole-3-Acetic Acid in Commelina communis L. New Physiologist 90(2).

Pérez, J. C. D., Shackel, K. A., and Sutter, E. G. (1995). Effects of In Vitro formed Roots and Acclimatization on Water Status and Gas Exchange of Tissue cultured Apple Shoots. J. Amer. Soc. Hort. Sci. 120(3): 435-440.

Pospisilova, J , Ticha I, Kadlecek P, Haisel D and Plazakova S (1999). Acclimatization of Micropropagated Plants to Ex Vitro Conditions. Biologia Plantarum 42 (4): 481-497.
Pospíšilová, J., Wilhelmová, N., Synková, H., Čatský, J., Krebs, D., Tichá, I., Hanáčková, B., and Snopek, J. (1998). Acclimation of Tobacco Plantlets to Ex vitro Conditions as Affected by Application of Abscisic Acid. Journal of Experimental Botany 49(322): 863869.

Preece, J. E., and Sutter, E. G. (1991). Acclimatization of Micropropagated Plants to the Greenhouse and Field. Micropropagation 71-93.

Quatrini, P., Gentile, M., Carimi, F., Pasquale, F. D. and Puglia, A. M. (2003). Effect of native arbuscular mycorrhizal fungi and Glomus mosseae on Acclimatization and Dvelopment of Micropropagated Citrus limon (L.) Burn. J. Hort. Sci. \& Biotech. 78(1): 3945.

Rahman, M. A., and Blake, J. (1988). Factors Affecting In Vitro Proliferation and Rooting of Shoots of Jackfruit (Artocarpus heterophyllus Lam.). plant Cell, Tissue and Organ Culture 13(3): 179-187.

Schubert, A., and Lubraco, G. (2000). Mycorrhizal Inoculation Enhances Growth and Nutrient Uptake of Micropropagated Apple Rootstocks During Weaning in Commercial Substrates of High Nutrient Availability. Applied Soil Ecology 15(2): 113-118.

Shackel, K. A., Novello, V., and Sutter, E. G. (1990). Stomatal Function and Cuticular Conductance in Whole Tissue-cultured Apple Shoots. J. Amer. Soc. Hort. Sci. 115(3): 468-472.

Skirvin, R. M., and Sriskandarajah, S. (1993). The Use of Fogging and Phototron Units to Acclimatize in Vitro-derived Apple Shoots. HortTechnology 3(2): 208-210.

Soares, B. D. O., and Miranda, V. S. (2016). Rooting In vitro and Ex vitro 
acclimatization of citrus cultivars. Revista de Ciências Agrárias / Amazonian Journal of Agricultural and Environmental Sciences 59(2): 144-151. Uzaribara, E., Ansari, H., Nachegowda, V., Taj, A., and Sathyanarayana, B. N., (2015). Acclimatization of In Vitro Propagated Red Banana (Musa acuminata) Plantlets. The Bioscan 10(1): 221-224.

Wardle, K., and Short, K. C. (1983). Stomatal Response of In vitro Cultured Plantlets. I. Responses of Epidermal Strips of Chrysanthemum to Environmental Factors and Growth Regulators. Biochemie und Physiologie der Pflanzen 178(8): 619-624.

Wetzstein, H. Y., and Sommer, H. E. (1983). Leaf Anatomy of Tissue-cultured Liquidambar styraciflua during Acclimatization. Amer. J. Bot. 69(10): 1579-1586.

Wright, S. T. C., and Hiron, R. W. P. (1969). (+)-Abscisic Acid, the Growth Inhibitor Induced in Detached Wheat Leaves by a Period of Wilting. Nature 224(5220):
719-720.

Wu, Q. S., Zou, Y. N., and Wang, G. Y. (2011). Arbuscular Mycorrhizal Fungi and Acclimatization of Micropropagated Citrus. Journal Communications in Soil Science and Plant Analysis 42(15): 1825-1832.

Yue, D., Gosselin, A., and Desdardins, Y. (1993). Re-examination of the Photosynthetic Capacity of In Vitro Cultured Strawberry Plantlets. Amer. Soc. For Hort. Sci. 118(3): 419-424.

Zemke, J. M., Pereira, F., Lovato, P. E., and Silva, A. L. D. (2003). Evaluation of substrates for mycorrhization and weaning of two micropropagated grapevine rootstocks. Pesquisa Agropecuaria Brasileira 38 (11): 13091315.

Ziv, M., Schawarts, A., and Fleminger, D. (1987). Malfunctioning Stomata in Vitreous Leaves of Carnation (Dianthus caryophyllus) Plants Propagated In Vitro; Implications for Hardening. Plant Science 52: 127-134.

\section{How to cite this article:}

Rohit Mahendra, Nidhi Chauhan, Jyoti Bharti Sharma, Kanchan Rana and Manish Bakshi. 2020. Ex-vitro Establishment of Tissue Cultured plants in Fruit Crops-A Review. Int.J.Curr.Microbiol.App.Sci. 9(11): 3321-3329. doi: https://doi.org/10.20546/ijcmas.2020.911.397 